IJBPAS, February, Special Issue, 2022, 11(2): 171-177

ISSN: 2277-4998

International Journal of Biology, Pharmacy

and Allied Seiences (IJBPAS)

'A Bridge Betusen caboratory and QRader'

Www.ijbpas.com

\title{
ELEVATED D-DIMER LEVELS IN COVID-19 PATIENTS \\ CAUSING ACUTE MESENTERIC ISCHEMIA
}

\section{MODI PJ ${ }^{1 *}$, NERLEKAR HV $^{2}$ AND KAPDI $S^{3}$}

1: Junior Resident, Department of Surgery, Krishna institute of Medical Sciences

Deemed To be University, Karad, Maharastra (India)

2: Associate professor, Department of Surgery, Krishna institute of Medical Sciences

Deemed To be University, Karad, Maharastra (India)

3: Senior resident, Department of Surgery, Krishna institute of Medical Sciences

Deemed To be University, Karad, Maharastra (India)

*Corresponding Author: Dr. Parth J Modi: E Mail: parth.31modi94@gmail.com

Received $12^{\text {th }}$ July 2021; Revised $14^{\text {th }}$ Aug. 2021; Accepted $27^{\text {th }}$ Oct. 2021; Available online $15^{\text {th }}$ Feb. 2022

https://doi.org/10.31032/IJBPAS/2022/11.2.1023

ABSTRACT

\section{BACKGROUND}

The pathology of Covid-19 virus mainly involves respiratory system but not restricted to it. The virus involves multiple organ systems.

\section{AIM}

This study aims to assess the corelation of deranged coagulation profile in covid 19 patient with acute mesenteric ischemia.

\section{OBJECTIVES:}

a) A deranged coagulation profile in COVID-19 patients causing acute mesenteric ischemia.

b) increased mortality in acute mesenteric ischemia with COVID-19 patients with elevated D-dimer and fibrinogen level.

\section{INTRODUCTION}

The COVID-19 pandemic in India is a caused by severe acute respiratory part of the universal pandemic of syndrome coronavirus 2 [1]. As of 17 coronavirus disease 2019 (COVID-19) August 2021, India has the second- 
highest number of confirmed cases in the world with 32.2 million reported cases of COVID-19 infection and first being United States of America. The third-highest number of COVID-19 deaths (432,079 deaths) [2]. However, these figures display severe underreporting.

India's vaccination programme underway on 16 January 2021 with Covishield and the indigenous Covaxin. As of 31 october 2021, 1.06 million vaccine doses have been administered in India. Most people who get COVID19 are unvaccinated. Vaccines are not $100 \%$ effective at preventing COVID19 infection, some people who are fully vaccinated may still get COVID-19. An infection of a fully vaccinated person is known as a "vaccine breakthrough infection."

Thromboembolic disorder like DVT, pulmonary embolism and acute mesenteric ischemia incidence noted in covid patients. Acute mesenteric ischemia is associated with high mortality and morbidity. High index of suspicion corelating with history and thorough physical examination helps in immediate diagnostic and therapeutic management. Thus reducing the mortality and morbidity associated with this disorder [3].
Gold standard investigation of choice for AMI is CT Angiography. In severe covid 19 patient along with HRCT, CTA is also done to rule out pulmonary embolism. CTA abdomen can also be performed simultaneously in clinically suspicious patient of AMI [4].

Coagulation studies like D-dimer, fibrinogen, platelet count are also done routinely in all covid patients [5].

In severe covid 19 patient CTA lung and CTA abdomen can be done simultaneously to rule out pulmonary embolism and AMI.

$\mathrm{Ct}$ findings in mesenteric ischemia include diffuse bowel dilatation, thickened bowel walls, ascites, hyperdense mural haemorrhage, pneumatosis. Venous gas or free intraperitoneal air suggests frank perforation [6].

\section{MATERIALS AND METHODS}

This is an observational study done in COVID-19 positive patients diagnosed with acute mesenteric ischemia. The investigation and treatment data was collected from the medical records at Krishna Institute of Medical Sciences (karad).

\section{Inclusion criteria:}

1. COVID-19 positive patients with CT diagnosed acute mesenteric ischemia 


\section{Exclusion criteria:}

1. Patients not willing to take part in the study
2. COVID 19 negative patients

3. Past history of cardiovascular or cerebrovascular diseases.

Table 1.0

\begin{tabular}{|c|c|c|c|c|c|c|c|c|c|}
\hline $\begin{array}{c}\text { S.n } \\
\text { o }\end{array}$ & $\begin{array}{c}\text { Age/Gend } \\
\text { er }\end{array}$ & $\begin{array}{c}\text { Diagnos } \\
\text { is of } \\
\text { COVID }\end{array}$ & $\begin{array}{c}\text { General } \\
\text { condition }\end{array}$ & $\begin{array}{c}\text { Comorbiditi } \\
\text { es }\end{array}$ & $\begin{array}{c}\text { D-dimer } \\
\text { level } \\
(\mu \mathrm{g} / \mathrm{ml})\end{array}$ & $\begin{array}{c}\text { Fibrino } \\
\text { gen } \\
(\mathrm{mg} / \mathrm{dl})\end{array}$ & $\begin{array}{c}\text { Platelet } \\
\text { count }\end{array}$ & $\begin{array}{c}\text { interventio } \\
\text { n }\end{array}$ & $\begin{array}{c}\text { outcom } \\
\text { e }\end{array}$ \\
\hline 1. & $57 y / M$ & $\begin{array}{c}\text { RTPCR } \\
\text { HRCT- } \\
(\mathbf{5 0 -} \\
\mathbf{5 5 \% )}\end{array}$ & $\begin{array}{c}\text { ARDS } \\
\text { with O2 } \\
\text { mask }\end{array}$ & HTN & 4.8 & 1649 & $\begin{array}{c}3.77 \\
\text { lakh/cu.m } \\
\text { m }\end{array}$ & $\begin{array}{c}\text { conservativ } \\
\text { e }\end{array}$ & expired \\
\hline 2. & $70 \mathrm{y} / M$ & $\begin{array}{c}\text { RTPCR } \\
\text { HRCT } \\
(15 / 25)\end{array}$ & $\begin{array}{c}\text { ARDS on } \\
\text { mechanic } \\
\text { al } \\
\text { ventilatio } \\
\text { n } \\
\end{array}$ & $\begin{array}{c}\text { HTN } \\
\text { Type II DM } \\
\text { IHD }\end{array}$ & 1.8 & 604 & 60,000 & $\begin{array}{l}\text { Conservati } \\
\text { ve as not fit } \\
\text { for } \\
\text { anaesthesia }\end{array}$ & expired \\
\hline 3. & $65 \mathrm{y} / \mathrm{F}$ & $\begin{array}{c}\text { RTPCR } \\
\text { HRCT } \\
(7 / 25)\end{array}$ & $\begin{array}{l}\text { ARDS on } \\
\text { CPAP }\end{array}$ & $\begin{array}{c}\text { HTN } \\
\text { Type II DM } \\
\text { Obesity }\end{array}$ & 2.16 & 1456 & $\begin{array}{c}3.67 \\
\text { lakh/cu.m } \\
\text { m }\end{array}$ & $\begin{array}{c}\text { Explorator } \\
y \\
\text { laprotomy }\end{array}$ & $\begin{array}{c}\text { Expire } \\
\text { d }\end{array}$ \\
\hline 4. & $62 y / M$ & $\begin{array}{l}\text { RTPCR } \\
\text { HRCT } \\
(14 / 25)\end{array}$ & $\begin{array}{c}\text { ARDS } \\
\text { with O2 } \\
\text { mask }\end{array}$ & $\begin{array}{l}\text { HTN } \\
\end{array}$ & 1.15 & 330 & $\begin{array}{c}1.80 \\
\text { lakh/cu.m } \\
\text { m }\end{array}$ & $\begin{array}{c}\text { Explorator } \\
y \\
\text { laprotomy }\end{array}$ & Alive \\
\hline 5. & $50 \mathrm{y} / M$ & $\begin{array}{l}\text { RTPCR } \\
\text { HRCT } \\
(10 / 25) \\
\end{array}$ & $\begin{array}{c}\text { Stable 0ff } \\
\text { O2 }\end{array}$ & $\begin{array}{c}\text { HTN } \\
\text { Obesity }\end{array}$ & 0.75 & 236 & $\begin{array}{c}1.63 \\
\text { lakh/cu.m } \\
\text { m } \\
\end{array}$ & $\begin{array}{c}\text { Explorator } \\
\mathbf{y} \\
\text { laprotomy } \\
\end{array}$ & Alive \\
\hline
\end{tabular}

M: male, F: female, RT-PCR: real-time reverse transcription polymerase chain reaction assay, HTN: hypertension, DM: diabetes mellitus, IHD: ischemic heart disease, HRCT: High -resolution computed tomography, ARDS: acute respiratory distress syndrome.

\section{RESULTS}

Age of the patients:

The median age for males is 60 and for females is 65 .

\section{Mode of diagnosis:}

Covid positive status diagnosed by RTPCR and HRCT. Acute mesenteric ischemia diagnosed by CT Angiography abdomen.

\section{COMORBIDITIES:}

Hypertension was the most common comorbidity subsequently diabetes and obesity.

\section{TREATMENT MODALITY:}

3 patients managed with exploratory laparotomy followed by resection and anastomosis
2 patients were managed conservatively

\section{MORTALITY:}

There is a $60 \%$ overall mortality in AMI. 1 out of the 3 patients posted for exploratory laparotomy expired and the two patients treated conservatively had succumbed.

\section{D-DIMER:}

A normal D-dimer value is less than 0.5. All the above 5 patients had an elevated D-dimer values

\section{FIBRINOGEN:}

A normal fibrinogen level is 200$400 \mathrm{mg} / \mathrm{dl}$. 3 out of the 5 patients had raised fibrinogen level above 400 $\mathrm{mg} / \mathrm{dl}$. And all the 3 patients had expired. 


\section{PLATELET:}

A normal platelet value is 1.5-4.5 lac/ml.1 patient had less than normal level and had succumbed.

\section{RESULTS:}

A total of 5 covid positive patients who have been diagnosed with acute mesenteric ischemia were managed since covid outbreak. An elevated Ddimer level is present in all patients with $\mathrm{CT}$ proven acute mesenteric ischemia. Patients with markedly deranged coagulation profile were managed conservatively. Patients with both elevated D-dimer and fibrinogen levels had higher mortality than those with only either elevated. HRCT score and the respiratory status affected the intervention modality. Patients with associated medical comorbidities also increased the mortality.
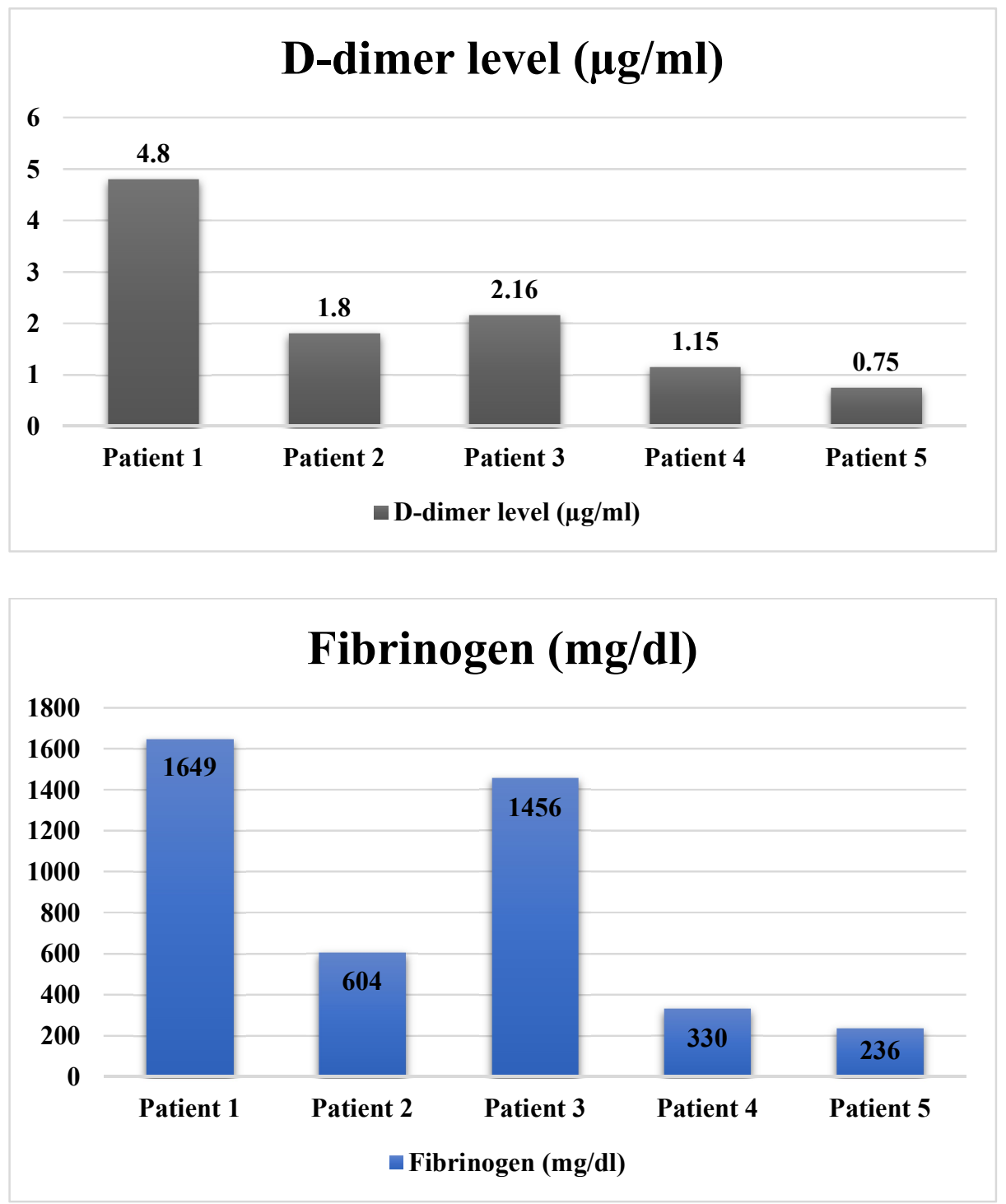


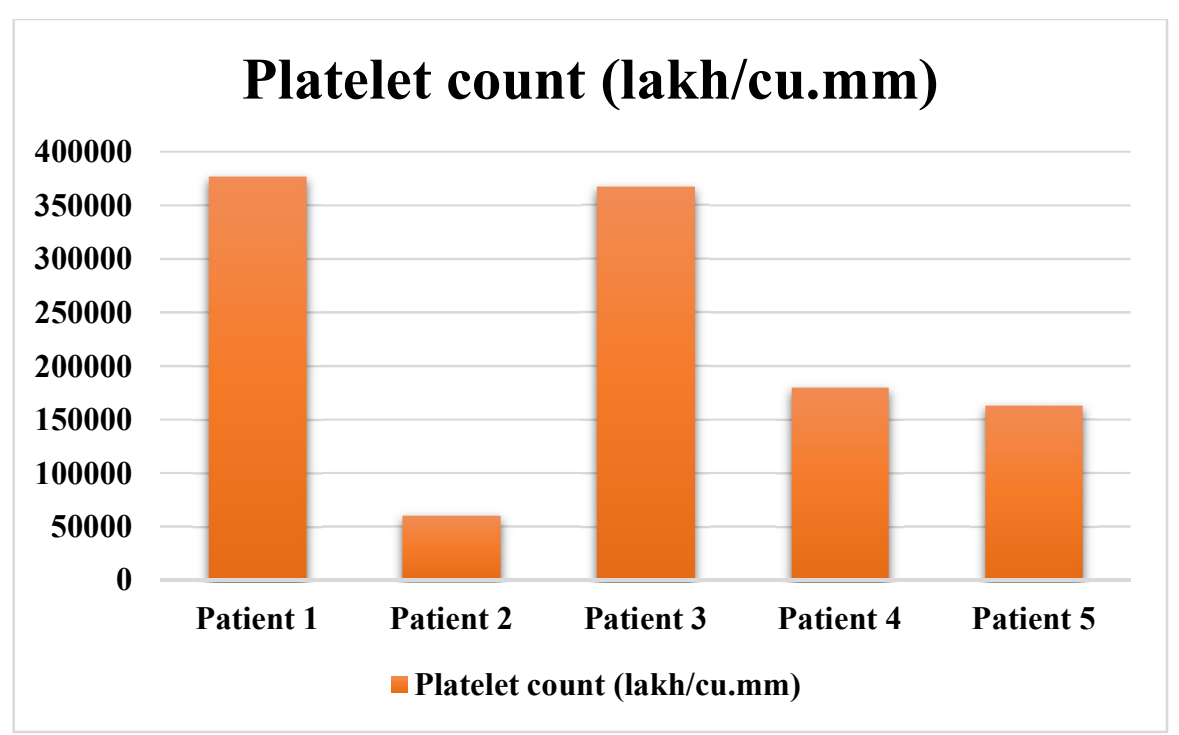

\section{CONCLUSION:}

Covid positive patient with elevated $d$ dimer levels and abdominal symptoms must be evaluated at the earliest. Investigations for the evaluation of abdominal vessels should be performed on urgent basis, followed by immediate treatment with anticoagulants conservatively or surgically by exploratory laparotomy.

\section{DISCUSSSION}

Severe cases of Corona virus disease are often characterized by hyperinflammation, disproportion of renin-angiotensin aldosterone system, and particular form of vasculopathy, thrombotic microangiopathy and intravascular coagulopathy [7].

A collective finding in all COVD -19 patients is high fibrinogen and D-dimer levels which are related with poor prognosis. Markedly hypercoagulable thromboelastometry profiles were detected in COVID-19 patients [8]. Patients with acute respiratory failure present with severe hypercoagulability rather than consumptive coagulopathy. Fibrin formation and polymerization may prejudice to thrombosis and correlate with worse outcome [9].

Mesenteric ischaemia is one of the most disastrous vascular disorders with mortality rates ranging from 50\%-75\%. Early recognition and early treatment before the onset of irreversible intestinal ischemia are essential to improve the outcome if full thickness ischemia occurs in the bowel wall, intestinal perforation ensues, which will lead to peritonitis.

The severe inflammatory state subordinate to COVID-19 leads to a severe derangement of haemostasis that has been recently described as a state of 
disseminated intravascular coagulation (DIC) defined as decreased platelet count, increased fibrin degradation products (FDP) such as D-dimer, as well as low fibrinogen. There is a compensatory platelet production response in severely ill patients with systemic immune and coagulation activation and thus there is a rational platelet count. Severe thrombocytopenia is only rarely reported in COVID-19 patients [10].

A total of four mechanisms occurring either in isolation or as a combination result in severe complication in covid 19.

The first being hypercoagulable state resulting in mesenteric vascular thrombosis.

Second being, raised Von-Willebrand causing endothelial dysfunction with resultant vascular thrombosis.

Third cause being an ACE2 receptor which is a counter regulatory peptide that converts Angiotensin -II into Angiotensin -I, this results in the attenuation of the biological effects of the anti-thrombin -I receptor [11]. The cellular infection causes the release of pro-inflammatory cytokines, ARDS, myocarditis and hypercoagulability. The possibility of aggravation of acute coronary syndrome, induction of pulmonary embolism or appearance of DIC is increased. Hyper viscosity damages the endothelium also resulting in thrombosis.

Lastly, severe pneumonia in covid patient eventually end up in shock resulting in non-occlusive mesenteric ischemia.

AMI presents with abdominal pain, nausea or vomiting, loose stools, abdominal distension with deteriorating systemic condition. Blood investigations show elevated lactate levels and elevated FDP (D-dimer).

CT Angiography of abdomen is the investigation of choice.

\section{Acknowledgement}

I am thankful to Mrs Rupali Salunkhe for secretariat help, Krishna Institute of medical sciences Deemed to be University, Karad, Maharashtra (India)

\section{REFERENCES}

[1] World Health Organization, Coronavirus disease 2019 (COVID-19): situation report, 73.

[2] Ritchie H, Mathieu E, RodésGuirao L, Appel C, Giattino C, Ortiz-Ospina E, et al., Coronavirus pandemic (COVID-19), Our World in Data, 2020.

[3] Kerawala AA, Das B, Solangi A, Mesenteric ischemia in COVID-19 patients: A review of current 
literature, World journal of clinical cases, 9(18), 2021, 4700.

[4] Parry AH, Wani AH, Yaseen M, Acute mesenteric ischemia in severe coronavirus-19 (COVID19): possible mechanisms and diagnostic pathway, Academic radiology, 27(8), 2020, 1190.

[5] Zhang L, Yan X, Fan Q, Liu H, Liu $\mathrm{X}$, Liu Z, et al., D-dimer levels on admission to predict in-hospital mortality in patients with Covid-19, Journal of thrombosis and haemostasis, 18(6), 2020, 1324-9.

[6] A Beccara L, Pacioni C, Ponton S, Francavilla S, Cuzzoli A. Arterial mesenteric thrombosis as a complication of SARS-CoV-2 infection, European journal of case reports in internal medicine, 7(5), 2020.

[7] Levi M, Thachil J, Iba T, Levy JH, Coagulation abnormalities and thrombosis in patients with COVID-19, The Lancet Haematology, 7(6), 2020, e438-40.

[8] Haematology TL, COVID-19 coagulopathy: an evolving story, The Lancet, Haematology, 7(6), 2020, e425.

[9] Panigada M, Bottino N, Tagliabue P, Grasselli G, Novembrino C, Chantarangkul V, et al., Hypercoagulability of COVID-19 patients in intensive care unit: a report of thromboelastography findings and other parameters of hemostasis, Journal of Thrombosis and Haemostasis, 18(7), 2020, $1738-42$

[10] Henry BM, Vikse J, Benoit S, Favaloro EJ, Lippi G, Hyperinflammation and derangement of renin-angiotensinaldosterone system in COVID-19: a novel hypothesis for clinically suspected hypercoagulopathy and microvascular immunothrombosis, Clinica Chimica Acta, 507, 2020, 167-73.

[11] Barillà F, Bassareo PP, Calcaterra G, Romeo F, Mehta JL, Focus on clinical practice: angiotensinconverting enzyme 2 and corona virus 2019: pathophysiology and clinical implications, Journal of Cardiovascular Medicine, 21(9), 2020, 630-3. 